ЭЭГ, учитывая прогностическое значение соответствующей информации в сфере скоростных возможностей нервных процессов. 113 праворуких здоровых женщин в возрасте от 19 до 21, взявшие участие в тестировании, были разделены на две группы в зависимости от среднего значения их индивидуальной модальной частоты альфа-ритма, определённого в состоянии покоя, - групп с высокой и низкой индивидуальной модальной альфачастоты. Оценивали время простой сенсомоторной реакции и реакции выбора как критерий скоростных возможностей нервных процессов, коэфициенты когерентности частотных компонентов ЭЭГ во время состояния покоя и выполнения поочерёдных движений пальцев правой (ведущей) руки. Частотные субдиапазоны ЭЭГ были индивидуально определены для каждой испытуемой за алгоритмом W. Klimesh (2007). Полученные нами результаты свидетельствовали, что женщины с высокой модальной частотой альфа-ритма имели меньшее время простых сенсомоторных реакций и реакций выбора. Во время движения пальцев у женщин обеих групп фиксировали увеличение коэффициентов когерентности всех частотных субдиапазонов ЭЭГ в коре. В этих условиях у женщин с низкой $\alpha$-частотой установили высшую когерентность частотных компонентов ЭЭГ в лобных, передних височных и центральных участках и низшую - в задних височных и теменно-затылочных областях коры по сравнению с обследуемыми с высокой индивидуальной $\alpha$-частотой.

Коржик Ольга, Моренко Алевтина. Когерентність частотних компонентів ЕЕГ під час виконання почергових рухів пальців у жінок із різною модальною частотою альфа-ритму. Рухи верхніх кінцівок людини, зокрема рухи пальців, складають основу мануальної моторики в трудовій діяльності. Індивідуальні функціональні можливості моторної системи тієї чи іншої людини набувають критичного значення для успішного оволодіння низкою професій у сучасному соціумі. Тому наукова спільнота приділяє все більшу увагу проблемі індивідуальних особливостей мозкових процесів, які забезпечують моторне програмування маніпуляторних рухів. Мета нашого дослідження полягає в 3'ясуванні особливостей когерентності частотних компонентів ЕЕГ під час виконання почергових рухів пальців у жінок із високою і низькою модальною частотою $\alpha$-ритму ЕЕГ, ураховуючи прогностичне значення відповідної інформації у сфері швидкісних можливостей нервових процесів. 113 праворуких здорових жінок у віці від 19 до 21, які взяли участь у тестуванні, були розділені на дві групи залежно від середнього значення їхньої індивідуальної модальної частоти альфа-ритму, визначеного в стані спокою, - груп із високою й низькою індивідуальною модальною альфа-частотою. Оцінювали час простої сенсомоторної реакції та реакції вибору як критерій швидкісних можливостей нервових процесів, коефіцієнти когерентності частотних компонентів ЕЕГ у стані спокою та під час виконання почергових рухів пальців правої (провідної) руки. Частотні субдіапазони ЕЕГ були індивідуально визначені для кожної випробуваної за алгоритмом W. Klimesh (2007). Отримані результати свідчили, що жінки з високою модальною частотою альфа-ритму мали менший час простих сенсомоторних реакцій і реакцій вибору. У жінок обох груп виявляли збільшення коефіцієнтів когерентності в усьому частотному спектрі ЕЕГ у корі під час виконання почергових рухів пальців. У цих умовах у жінок із низькою $\alpha$-частотою встановили вищу когерентність частотних компонентів ЕЕГ у лобових, передніх скроневих і центральних ділянках та нижчу - у задніх скроневих і тім'яно-потиличних ділянках кори, порівняно з обстежуваними із високою індивідуальною $\alpha$-частотою.

Стаття надійшла до редколегії 28.10.2015 p.

УДК: $612.4 .05 ; 612.33 ; 612.018 .2$.

Ярослав Анасевич

\title{
Вплив надлишку та нестачі мелатоніну на продукцію супероксиду в тонкій кишці щурів
}

Нестача мелатоніну сприяє збільшенню продукції супероксиданіонрадикалу в тонкій кишці щурів від фагоцитарних електронно-транспортних ланцюгів, а надлишок - від мітохондріального окиснення, що відповідає антиоксидантним властивостям мелатоніну. Витік супероксиду 3 мікросомального електроннотранспортного ланцюга окиснення в обох випадках не змінювався.

Ключові слова: тонкий кишечник, супероксиданіонрадикал, гіпомелатонінемія, гіпермелатонінемія.

(C) Анасевич Я., 2015 
Постановка наукової проблеми та її значення. Біологічне значення мелатоніну зараз дуже активно досліджується («мелатоніновий бум», навіть створено журнал «Journal of Pineal Research»). Згідно $з$ дослідженнями, основним джерелом мелатоніну, що циркулює в крові, є епіфіз, але виявлений i паракринний синтез мелатоніну практично у всіх органах та тканинах: тимусі, шлунковокишковому тракті, гонадах, сполучній тканині. У дослідженнях на пінеалектомованих тваринах продемонстровано наявність мелатоніну в органах шлунково-кишкового тракту [16, с. 313]. Ці факти свідчать про синтез мелатоніну органами шлунково-кишкового тракту (ШКТ). Але навіть на підставі цих досліджень можливо вважати, що мелатонін відіграє важливу роль у фізіології ШКТ і порушення його секреції може бути причиною різних патологій органів ШКТ.

$€$ велика група населення, яка працює в нічні зміни, існує в умовах цілодобового освітлення (великі міста, полярний день, сон при світлі), яке блокує синтез та секрецію мелатоніну епіфізом. Крім того, є можливість неконтрольованого вживання мелатоніну в якості снодійного. Зараз велике значення приділяється прооксидантно-антиоксидантному балансу органів й організму в цілому, систем захисту та пошкодження, універсальній адаптації [7, с. 552; 15]. Але праць, що стосуються впливу мелатоніну на продукцію супероксиду в тонкій кишці щурів, немає.

Аналіз досліджень цієї проблеми. Мелатонін має антистресову, антиканцерогенну, антигеріатричну, антиоксидантну дії $[1 ; 6 ; 7$, с. 552; 15]. Мелатонін синтезується для всього організму в епіфізі та для локальної дії в клітинах APUD-системи. В епіфізі синтез проходить тільки тоді, коли на очі не потрапляє світло. Мелатонін $є$ нейромедіатором, імуностимулятором, гормоном, який має майже на всіх клітинах організму три типи мембранних рецепторів, що діють крізь аденілатциклазну або кальцієву месенджерні системи, та ядерні рецептори, які впливають на експресію більш ніж 250 генів. Як нейромедіатор, він має сомногенні властивості, сприяє секреції ГАМК, активує проведення нервових імпульсів, як імуностимулятор - активує поділ стовбурових клітин червоного кісткового мозку, стимуляційно регулює тимус та лімфоцити, як гормон - впливає на секрецію рілізингів гіпоталамусу й блокує тропіни гіпофізу, особливо гонадотропінів, інгібує проліферацію більшості стовбурових клітин $[1 ; 10$, с. 28], проявляє властивості непрямого антиоксиданту за допомогою активації експресії генів антиоксидантних ферментів. Мелатонін $є$ також прямим антоксидантом, який діє ароматичним ядром і воднем аміногрупи $[2,5 ; 17$, с. 246$]$.

Прооксидантно-антиоксидантна система складається з генерації активних форм кисню, які ініціюють неферментативне вільнорадикальне пероксидне окиснення біополімерів, що лімітується антиоксидантним захистом. Найбільш слабка активна форма кисню - супероксиданіонрадикал (супероксид), але з нього утворюються сильніші (пероксиди водню, сінглетний кисень, гідроксилрадикал). Утворюється супероксид: 1) реакцією катіонів металів змінної валентності з відновниками та $\mathrm{O}_{2}$; 2) при функціонуванні флавінових і гемових оксидаз; 3) витоком із мітохондріальної й мікросомальної електронно-транспортних ланцюгів; 4) цілеспрямовано при неспецифічному імунному захисті 3 фагоцитів (дихальний вибух). У крові нейтрофіли (а також моноцити) мають НАДФН-оксидазу (електронно-транспортний ланцюг НАДФН $\rightarrow$ ФАДН $2 \rightarrow$ цитохром 558 нм за довжиною хвилі світопоглинання або -245 мв за потенціалом), яка з $\mathrm{O}_{2}$ утворює одноелектронним переносом супероксид. Активується ланцюг через кальцієву месенджерну систему. У тканинах при запаленнях діють нейтрофіли, яких на другій фазі запалення замінюють макрофаги, що в нормі містяться в тканинах як нащадки моноцитів. Макрофаги містять ксантиноксидазу. Ксантиноксидаза - димер - містить 2 або 3 субодиниці, у кожній із яких є ФАД, залізо-сірчаний кластер $\mathrm{Fe}_{2}-\mathrm{S}_{2}$, птерин, багато цистеїнів для дисульфидних містків між субодиницями, молібден, причому $\mathrm{Mo}^{+5}$ має зв'язки - два 3 ФАД, два 3 птерином, один із сіркою цистеїну, можливо, одну з групою -S-SH. Ксантиноксидаза формується 3 ксантиндегідрогенази лімітованим протеолізом кальційзалежною протеїназою або окисненням дисульфідних містків, переважно при гіпоксії. Окиснення заліза у $\mathrm{FeS}$-центрі дає супероксид; ФАД дегідрує субстрат, даючи активний семіхінон. ФАД дегідрує навіть воду, утворюючи гідроксилрадикал і ФАДН $\mathrm{H}_{2}$; останній відновлює супероксид у $\mathrm{H}_{2} \mathrm{O}_{2}$. Електрон ФАД може відновлювати залізо, а два гідроксилрадикали сполучаються в $\mathrm{H}_{2} \mathrm{O}_{2}$. $\mathrm{Mo}^{+5}$ віддає електрон на $\mathrm{H}_{2} \mathrm{O}_{2} 3$ розщепленням іiі на $\bullet \mathrm{OH}$ та $\mathrm{OH}-, \mathrm{Mo}^{+6}$ зв'язує $\mathrm{OH}^{-}$і гідроксилює субстрат, віддаючи $\bullet \mathrm{OH}$ та окислюючись до $\mathrm{Mo}^{+5}$. Оскільки (молярно) на $2 \mathrm{FeS}$ приходиться 1 ФАД і 1 Mo, то супероксиду генерується в надлишку [14, с. 120].

Там, де існує можливість бактеріального забруднення з негативними наслідками, багато макрофагів та підвищена активність ксантиноксидази (молоко, сироватка крові, печінка й особливо тонкий 
кишечник). Але не досліджено джерела та кількість генерованого в тонкому кишечнику супероксиду при гіпомелатонінемії й гіпермелатонінемії [5, с. 147; 6].

Мета й завдання статті. Мета роботи - визначення джерел та кількості супероксиданіонрадикалу в тонкій кишці при гіпо- й гіпермелатонінеміях.

Виклад основного матеріалу й обгрунтування отриманих результатів дослідження. Дослідження проводили на щурах-самцях Wistar (три групи по п’ять тварин, середня маса - 160 г), яких утримували в стандартних умовах віварію при сталій температурі й вологості повітря, вільному доступі до води та їжі. Перша група - інтактна, що утримувалася при світловому режимі: 12 годин темнота; 12 годин - світло (термін - 30 діб). У другої групи для моделювання гіпомелатонінемії тварини утримували в режимі постійного освітлення (1000-1500 люкс) 30 діб. У третьої групи гіпермелатонінемію моделювали уведенням мелатоніну в харчовий раціон дозою 1 мг/кг маси тіла/добу й цілодобовою темрявою 30 діб [8]. Сезон дослідження - пізня весна, коли секреція мелатоніну - середня між максимумом узимку та мінімумом улітку [11, с. 41]. Тварин виводили 3 експерименту здійснюючи одномоментну декапітацію під кетаміновим наркозом (40,0 мг/кг маси тіла).

Джерела та кількість супероксиду визначали за НСТ-тестом [13, с. 65] в епітеліальній тканині тонкої кишки. Принцип методу полягає у відновленні водорозчинного жовтого нітросинього тетразолію (НСТ) супероксидом у гранули синього формазану, який елююється сумішшю диметилсульфоксиду 3 хлороформом. Інтенсивність забарвлення оцінюють при 540 нм на фотоелектроколориметрі. Результат виражали в нмоль $\cdot \mathrm{O}_{2}^{-1} /$ г/хв. Для установлення джерел проводили стимуляцію: НАДН для мітохондріального окиснення, НАДФН - для мікросомального окиснення, пірогеналом (або продігіозаном, зимозаном) - для фагоцитарного окиснення.

Визначали також відносну масу тонкої кишки.

Отримані цифрові дані обробляли методами варіаційної статистики для малих виборок із використанням для оцінки ймовірності різниць середніх для окремих груп даних за критерієм Стьюдента. За статистично достовірні брали зміни при р<0,05, а значення р у межах 0,1-0,05 вважали тенденцією до достовірності [3; 4].

Отримані в результаті дослідження дані наведено в табл. 1.

Таблиця 1

\section{Величини показників відносної маси тонкої кишки й кількості продукції із супероксиданіонрадикалу від різних джерел}

\begin{tabular}{|c|c|c|c|}
\hline Показник, що досліджується & $\begin{array}{c}\text { Норма } \\
(n=5)\end{array}$ & $\begin{array}{c}\text { Гіпомелатонінемія } \\
(n=5)\end{array}$ & $\begin{array}{c}\text { Гіпермелатонінемія } \\
(n=5)\end{array}$ \\
\hline Відносна маса тонкої кишки, \% & $4,83 \pm 0,20$ & $\begin{array}{l}2,36 \pm 0,14 \\
\mathrm{p}_{1}<0,001 *\end{array}$ & $\begin{array}{c}4,31 \pm 0,22 \\
\mathrm{p}_{1}<0,1 \\
\mathrm{p}_{2}<0,001 *\end{array}$ \\
\hline $\begin{array}{l}\text { НАДН - стимульований } \\
\text { (мітохондріальне окиснення) вихід } \\
\text { супероксиду, нмоль } \bullet_{2}^{-1} / 2 \times x 8\end{array}$ & $21,67 \pm 12,50$ & $27,59 \pm 4,74$ & $\begin{array}{c}19,40 \pm 2,31 \\
\mathrm{p}_{2}<0,1\end{array}$ \\
\hline $\begin{array}{l}\text { НАДФН - стимульований } \\
\text { (мікросомальне окиснення) } \\
\text { вихід супероксиду, нмоль } \bullet O_{2}^{-1} / 2 \times x 8\end{array}$ & $26,47 \pm 2,30$ & $24,92 \pm 5,97$ & $27,60 \pm 3,38$ \\
\hline $\begin{array}{l}\text { Пірогенал - стимульований } \\
\text { (фагоцитарне окиснення) вихід } \\
\text { супероксиду, нмоль } O_{2}^{-1} / 2 \times x 8\end{array}$ & $6,47 \pm 0,71$ & $\begin{array}{c}8,13 \pm 0,59 \\
\mathrm{p}_{1}<0,1\end{array}$ & $\begin{array}{c}6,49 \pm 0,37 \\
\mathrm{p}_{2}<0,05\end{array}$ \\
\hline
\end{tabular}

Примітка. * Значення, які статистично достовірно відрізняються в різних групах: $\mathrm{p}_{1}$ - належить до значень норми;

$\mathrm{p}_{2}$ - порівняння гіпо- та гіпермелатонінемії.

Порівнюючи однакові за терміном дії гіпомелатонінемії й гіпермелатонінемії, виявили, що при гіпомелатонінемії відносна маса тонкої кишки в 1,8 раза менша, ніж при гіпермелатонінемії ( $\left.\mathrm{p}_{2}<0,001\right)$. Майже удвічі відносна маса тонкої кишки при 30-денній гіпомелатонінемії менша за умовну норму. На $10 \%$ із тенденцією до достовірності коефіцієнт маси тонкої кишки при нестачі мелатоніну менший за умовну норму, що можна вважати наслідком дисбалансу продукції мелатоніну. 
Як видно з результатів дослідження, тонка кишка виявилася відносно стійкою за генерацією супероксиду до дії гіпо- й гіпермелатонінемії. Але в умовах гіпомелатонінемії пірогенал стимулює збільшення на $26 \%$ викиду супероксиданіонрадикалу з макрофагів лімфатичних вузлів тонкого кишечнику та нейтрофілів капілярної крові. Ураховуючи, що в макрофагах джерелом супероксиду $є$ ксантиноксидаза, можна припустити Са-залежну активацію переходу ксантиндегідрогенази в активну ксантиноксидазу при зниженні продукції мелатоніну епіфізом. Не виключена можливість дії мелатоніну місцевої продукції.

При надлишку мелатоніну продукція супероксиду з мітохондріального окислення в 1,4 раза менша, ніж при його нестачі. Це вказує на суттєву антиоксидантну активність мелатоніну й можливе зниження рівня мітохондріального окиснення.

Генерація супероксиду з мікросомального окислення практично однакова в нормі, гіпо- та гіпермелатонінемії.

Стимульований пірогеналом дихальний вибух фагоцитів фактично проявився при гіпомелатонінемії, де продукція супероксиду в 1,3 раза більша ( $\left.\mathrm{p}_{2}<0,05\right)$. Тому фагоцитарна продукція супероксиду в тонкій кишці при гіпермелатонінемії, хоча й відповідає нормі, але на $20 \%\left(\mathrm{p}_{2}<0,05\right)$ менша від значення аналогічного показника при гіпомелатонінемії. Мабуть, у нормі й при гіпермелатонінемії мелатоніну достатньо для пригноблення нестимульованої активності фагоцитів. Можна передбачити, що при гіпермелатонінемії можливе блокування якихось ланок регуляції прооксидантно-антиоксидантної системи.

Ураховуючи, що надлишок і нестача біологічно активної речовини може спричиняти суттєві порушення регуляції метаболізму [9, с. 42], рекомендуємо вважати статистично достовірними відмінності при $\mathrm{p}<0,1$.

Висновки та перспективи подальшого дослідження. Отже, у тонкій кишці хронічна гіпомелатонінемія сприяе збільшенню продукції від фагоцитарних електронно-транспортних ланцюгів, а гіпермелатонінемія - від мітохондріального окиснення, що відповідає антиоксидантним властивостям мелатоніну.

У подальших дослідженнях планується визначати рівень прооксидантно-антиоксидантного балансу й усмоктування в тонкій кишці при різній забезпеченості організму мелатоніном.

\section{Джерела та література}

1. Анисимов В. Н. Мелатонин: роль в организме и применение в клинике / В. Н. Анисимов - СПб. : Система, 2007. $-40 \mathrm{c}$.

2. Барабой В. А. Антиокислительная и биологическая активность мелатонина / В. А. Барабой // Укр. біохім. журн. $-2000 .-$ T.72, N3. - C. 5-11.

3. Деркач М. П. Курс варіаційної статистики / М. П. Деркач, Р. Я. Гумецький, М. Є. Чабан. - К. : Вища шк., 1977. -208 c. - C. 25.

4. Лакин Г. Ф. Биометрия / Г. Ф. Лакин. - М. : Высш. шк., 1968. - 293 с.

5. Мелатонин в лечении язвенной болезни двнеадцатиперстной кишки / [Н. К. Малиновская, Ф. И. Комаров, С. И. Рапопорт та ін.]. - М. : Ид. медпрактика, 2003. - Гл. 9. - С. 147-162.

6. Мелатонин в физиологии и патологии желудочно-кишечного тракта / [В. Н. Анисимов, И. М. Кветной, Ф. И. Комаров та ін.]. - М. : Сов. спорт, 2000. - 184 с.

7. Особенности морфологии карциномы легкого Льюиса на фоне коррекции опухолевого роста мелатонином и 3-гидроксипиридином / [Н. А. Плотникова, Н. А. Пятаев, П. М. Канаев та ін.] // Фундаментальные исследования. - № 10-3. - 2014. - С. 552.

8. Пішак В. П. Шишкоподібне тіло і біохімічні основи адаптації / В. П. Пішак. - Чернівці : Медакадемія, 2003. $-152 \mathrm{c}$.

9. Проблема нормы в токсикологии / [И. М. Трахтенберг, Р. Е. Сова, В. О. Шефтель, Ф. А. Оникиенко]. М. : Медицина, 1991. - 208 с. - С. 42-43.

10. Смирнов А. Н. Ядерные рецепторы мелатонина / А. Н. Смирнов // Биохимия. - 2001. - Т. 66, N1. - С. $28-36$.

11. Турчина С. И. Сезонные ритмы продукции мелатонина и иммунореактивности у здоровых детей / С. И. Турчина, Н. В. Шляхова // Всероссийская научно-практическая конференция 50 лет мелатонину: итоги и перспективы исследований : тезисы докладов. - СПб., 2008. - С. 41.

12. Харченко А. О. Вплив мелатоніну на процеси перекисного окислення ліпідів у шлунку щурів в умовах моделювання іммобілізаційного стресу / А. О. Харченко, О. О. Цвях // Науковий вістник МНУ ім. В. О. Сухомлинського «Актуальні проблеми біології та екології. Біологічні науки». - Вип. 1. - 2013. C. $146-151$. 
13. Цебржинский О. И. Количественное определение супероксида НСТ-тестом в тканях / О. И. Цебржинский // Організація токсикологічної допомоги в Україні : тези доп. наук.-практ. конф. - К., 2002. С. $65-66$.

14. Цебржинский О. И. Некоторые аспекты антиоксидантного статуса / О. И. Цебржинский // Физиология и патология перекисного окисления липидов, гемостаза и иммуногенеза. - Полтава, 1992. - С. 120-155.

15. Antioxidant and antiapoptotic properties of melatonin restore intestinal calcium absorption altered by menadione / [A. Carpentieri, A. Marchionatti, V. Areco et al.] // Molecular and Cellular Biochemistry. - 2014. V. 387. - Issue 1. - P. 197-205.

16. Bubenik G. A. Localization of melatonin in the digestive tract of the rat: effect of maturation, diurnal variation, melatonin treatment and pinealectomy / G. A. Bubenik // Horm. Res. - 1980. - V. 12. - P. $313-323$.

17. Reiter R. J. Melatonin: Lowering the High Price of Free Radicals / R. J. Reiter // News Physiol. Sci. - 2000. Vol. 15. - P. 246-250.

Анасевич Ярослав. Влияние избытка и недостатка мелатонина на продукцию супероксида в тонкой кишке крыс. В тонкой кишке крыс недостаток мелатонина на протяжении 30 суток (круглосуточное освещение 1000-1500 лк) способствует увеличению продукции супероксиданионрадикала от фагоцитарных электороннотранспортных цепей, а избыток мелатонина (содержание крыс в темноте и пероральное введение мелатонина в ежедневной дозе 1 мг/кг массы тела) - от митохондриального окисления, что отвечает антиоксидантным способностям мелатонина. Вытек супероксида с микросомальной электронно-транспортной цепи окисления в обоих случаях не изменялся. При сравнении одинаковых по сроку действия недостатка и избытка мелатонина оказалось, что при недостатке относительная масса тонкой кишки в 1,8 раза меньше, чем при избытке. Почти в два раза относительная масса тонкой кишки при 30-дневном недостатке мелатонина меньше условной нормы. На 10 \% коэффициент массы тонкой кишки при избытке мелатонина меньше условной нормы, можно оценить как следствие дисбаланса продукции мелатонина.

Ключевые слова: тонкий кишечник, супероксиданионрадикал, гипомелатонинемия, гипермелатонинемия.

Anasevych Jaroslav. Effect of Excess and Shortage of Melatonin on Superoxide Production in the Small Intestine of Rats. In the small intestine of rats lack of melatonin for 30 days (lighting 1000-1500 lux) increases production by phagocytic elektoronno superoksidanionradikal transport chains, and the excess of melatonin (the content of rats in the dark, and oral administration of melatonin in a daily dose of $1 \mathrm{mg} / \mathrm{kg}$ body weight) - from mitochondrial oxidation, which corresponds to the antioxidant capacity of melatonin. Emerging superoxide with microsomal electron transport chain oxidation in both cases did not change. When comparing the same for the term of the shortage and excess of melatonin it was found that the shortage of the relative weight of the small intestine is 1,8 times less than the excess. Almost twice the relative weight of the small intestine in a 30-day conditional lack of melatonin is less than normal. $10 \%$ weight ratio of the small intestine with an excess of melatonin less conventional standards, can be estimated as a result of an imbalance of melatonin production.

Key words: small intestine, superoxidanionradical, hipomelatoninnemia, hypermelatoninnemia.

Стаття надійшла до редколегії 28.09.2015 p.

УДК 613.84-055.2

\author{
Людмила Апончук, \\ Тетяна Шевчук, \\ Ніна Бернацька
}

\section{Аналіз показників розумової та фізичної працездатності в жінок-курців}

Проаналізовано та вивчено особливості стану показників розумової й фізичної працездатності в жіноккурців. Установлено, що в них рівень фізичної працездатності за визначенням індексу гарвардського стептесту відповідає слабкому (I група) та середньому (II група), що вказує на низький рівень функціонального стану серцево-судинної системи обстежуваних осіб. Дослідження розумової працездатності засвідчило, що в жінок-курців I й II груп показник розумової працездатності відповідає низькому рівню за шкалою оцінювання,

(С) Апончук Л., Шевчук Т., Бернацькка Н., 2015 